\title{
PELAKSANAAN LESSON STUDY DALAM PERKULIAHAN BIMBINGAN PERAWATAN ANAK
}

\author{
Marwah Febriyanti , Ana, Sunarsih \\ Program Studi Pendidikan Kesejahteraan Keluarga \\ FPTK Universitas Pendidikan Indonesia \\ Jl. Dr. Setiabudhi 207 Bandung \\ Email : ana_syarief@yahoo.com
}

\begin{abstract}
Abstrak. Penelitian ini bertujuan untuk mengungkap bagaimana "Pelaksanaan Lesson Study dalam Perkuliahan Bimbingan Perawatan Anak pada Program Studi Pendidikan Kesejahteraan Keluarga (PKK) angkatan 2011 FPTK-UPI". Lesson study baru diterapkan dalam proses perkuliahan Bimbingan Perawatan Anak (BPA) pada Program Studi Pendidikan Kesejahteraan Keluarga (PKK) FPTK-UPI. Metode yang digunakan pada penelitian ini adalah metode deskriptif analitik dengan pendekatan kualitatif. Subjek penelitian dalam penelitian ini terdiri dari 1 orang Dosen Model, 6 orang Pengamat (Observer), 1 orang fasilitator, dan 26 orang mahasiswa Prodi PKK angkatan 2011 FPTK-UPI yang mengikuti mata kuliah Bimbingan Perawatan Anak. Jumlah keseluruhan subjek penelitian adalah 34 orang. Teknik pengumpulan data yang digunakan dalam penelitian ini adalah wawancara, observasi (daftar checklist) dan studi dokumentasi. Pelaksanaan Open Lesson dalam Perkuliahan Bimbingan Perawatan Anak pada pokok bahasan Alat Permainan Edukatif APE) dengan pendekatan Mediated Learning Experience (MLE) dilakukan tiga siklus. Pada tahap Perencanaan (Plan), Pelaksanaan (Do), dan Refleksi (See) yang dilakukan oleh dosen model, fasilitator beserta dosen PKK FPTK UPI selaku observer sudah dilaksanakan dengan baik sesuai dengan pedoman lesson study.
\end{abstract}

Kata kunci : bimbingan perawatan anak, lesson study, mediated learning experience.

\begin{abstract}
This study aims to investigate the implementasion of lesson study in the Guidance of Fostering Child subject at the Family Welfare Education Program at FPTK-UPI. The research employed analytical descriptive method, using qualitative approach. The subjects were thirty-four, consisting of a model lecturer, six observers, one facilitator, and twenty-six students of the program's class of 2011 who enrolled in the subject. Data was collected through interviews, observation (checklist) and study of documentation. The Open Lesson of the subject was focused on the Educative Toys topic and using Mediated Learning Experience approach. It comprised three cycles as follows: Plan, Do, and See in which all research subjects, except the students, participated. All of these cycles had been conducted in accordance with the lesson study guide.
\end{abstract}

Keywords : Guidance of Fostering Child, lesson study, mediated learning experience.

\section{PENDAHULUAN}

Peningkatan mutu pendidikan dapat dimulai dengan meningkatkan mutu proses belajar mengajar. Seiring dengan tuntutan pendidikan, dalam proses pembelajaran seorang pendidik perlu menyusun strategi-strategi mengajar secara sistematis dan menciptakan suatu proses pembelajaran yang mampu memfasilitasi peserta didik terhadap materi pembelajaran untuk meningkatkan kemampuan peserta didik dalam belajar, serta melibatkan partisipasi aktif peserta didik atau 
pembelajaran berpusat pada peserta didik (student centered learning). Peningkatan mutu dalam proses pembelajaran dijelaskan pula dalam Peraturan Pemerintah No.19 Tahun 2005 tentang Standar Nasional Pendidikan, Bab IV pasal 19 ayat 1 yang menyatakan bahwa:

Proses pembelajaran pada satuan pendidikan diselenggarakan secara interaktif, inspiratif, menyenangkan, menantang, memotivasi peserta didik untuk berpartisipasi aktif serta memberikan ruang yang cukup bagi prakarsa, kreativitas, kemandirian sesuai dengan bakat, minat, dan perkembangan fisik serta psikologi peserta didik.

Uraian di atas sejalan dengan salah satu tujuan Pendidikan Nasional poin 9 Undang-Undang Sistem Pendidikan Nasional No.20 Tahun 2003, yaitu:

Meningkatkan daya saing bangsa dengan menghasilkan lulusan yang mandiri, bermutu, terampil, ahli dan profesional, mampu belajar sepanjang hayat, serta memiliki kecakapan hidup yang dapat membantu dirinya dalam menghadapi berbagai tantangan dan perubahan". Pernyataan tersebut memberikan suatu gambaran bahwa proses perkuliahan di Perguruan Tinggi memerlukan inovasi dalam pembelajaran yang terus-menerus sehingga mampu mendorong peningkatan kualitas pembelajaran yang pada akhirnya akan menghasilkan Sumber Daya Manusia (SDM) atau lulusan yang mampu bersaing baik di tingkat regional, nasional, maupun internasional.

Oleh karena itu, perlu dilakukan inovasi pembelajaran melalui lesson study sebagai salah satu alternatif guna mengatasi permasalahan praktik pembelajaran. lesson study adalah suatu model pembinaan profesi pendidik melalui pengkajian pembelajaran secara kolaboratif dan berkelanjutan berlandaskan prinsip kolegalitas dan mutual learning untuk membangun komunitas belajar (learning community), (Gunawan Undang, 2009:12).

Hasil studi yang menunjukkan keunggulan dari kegiatan lesson study dilaporkan oleh Ibrohim (2011) bahwa pelaksanaan lesson study berbasis sekolah membawa manfaat di antaranya: (1) Guru menjadi termotivasi dan bangkit untuk membuat inovasi dalam pembelajarannya sehingga tercipta pembelajaran yang aktif, komunikatif, dan menyenangkan. Motivasi guru ini tumbuh karena adanya kerjasama yang positif, akademis, sinergis, dan kolaboratif di antara guru dalam kelompok MGMP sekolah; (2) Adanya persiapan pembelajaran yang lebih baik dari guru, baik persiapan mental, administrasi, dan penguasaan materi pelajaran; (3) Guru menjadi terdorong untuk belajar lebih banyak dalam hal materi, pemilihan strategi dan penggunaan model pembelajaran yang tepat demi kesuksesan pembelajarannya. 
Lesson study pada dasarnya adalah salah satu bentuk kegiatan pengembangan profesional dosen yang bercirikan dosen membuka pelajaran yang dikelolanya untuk dosen sejawat lainnya sebagai observer, sehingga memungkinkan dosen dapat berbagi pengalaman pembelajaran atau perkuliahan dengan rekan sejawatnya. Lesson study merupakan proses pelatihan dosen yang bersiklus, diawali dengan: (1) dosen merencanakan pelajaran melalui eksplorasi akademik terhadap materi ajar dan alat-alat pelajaran; (2) dosen melakukan pembelajaran berdasarkan rencana dan alat-alat pelajaran yang dibuat, mengundang sejawat untuk mengobservasi; dan (3) dosen melakukan refleksi terhadap pelajaran tadi melalui tukar pandangan, ulasan, dan diskusi dengan para observer. Oleh karena itu, implementasi program lesson study perlu dimonitor dan dievaluasi sehingga akan diketahui bagaimana keefektifan dan perolehan pihakpihak yang terlibat didalamnya.

Lesson study memiliki 4 (empat) tujuan utama, yaitu untuk: a) Memperoleh pemahaman yang lebih baik tentang bagaimana mahasiswa belajar dan dosen mengajar; b) Memperoleh hasil-hasil tertentu yang dapat dimanfaatkan oleh para dosen lainnya, di luar peserta lesson study; c) Meningkatkan pembelajaran secara sistematis melalui inkuiri kolaboratif; dan d) membangun sebuah pengetahuan pedagogis, dimana seorang dosen dapat menimba pengetahuan dari dosen lainnya.

Manfaat yang yang dapat diambil lesson study, diantaranya: (1) dosen dapat mendokumentasikan kemajuan kerjanya; (2) dosen dapat memperoleh umpan balik dari anggota lainnya; dan (3) dosen dapat mempublikasikan dan mendiseminasikan hasil akhir dari lesson study.

Lesson study dapat berfungsi sebagai salah satu upaya pelaksanaan program in-service training bagi para dosen. Upaya tersebut dilakukan secara kolaboratif dan berkelanjutan. Pelaksanaannya adalah di dalam kelas dengan tujuan memahami kegiatan belajar mahasiswa secara lebih baik. Kelompok dosen mengembangkan pembelajaran secara bersama-sama, salah seorang dosen ditugasi melaksanakan pembelajaran (dosen model), dosen lainnya mengamati (observer) belajar mahasiswa, proses ini dilaksanakan selama pembelajaran berlangsung. Pada akhir kegiatan, dosen berkumpul dan melakukan tanya jawab 
mengenai pembelajaran yang dilakukan, merevisi dan menyusun pembelajaran berikutnya berdasarkan hasil diskusi.

Secara lebih sederhana, siklus lesson study dilakukan melalui serangkaian kegiatan: Planning-Doing-Seeing (Plan-Do-See). Kegiatan tersebut diistilahkan sebagai kaji pembelajaran berorientasi praktik. Kegiatan-kegiatan tersebut dilukiskan seperti pada gambar 1 .

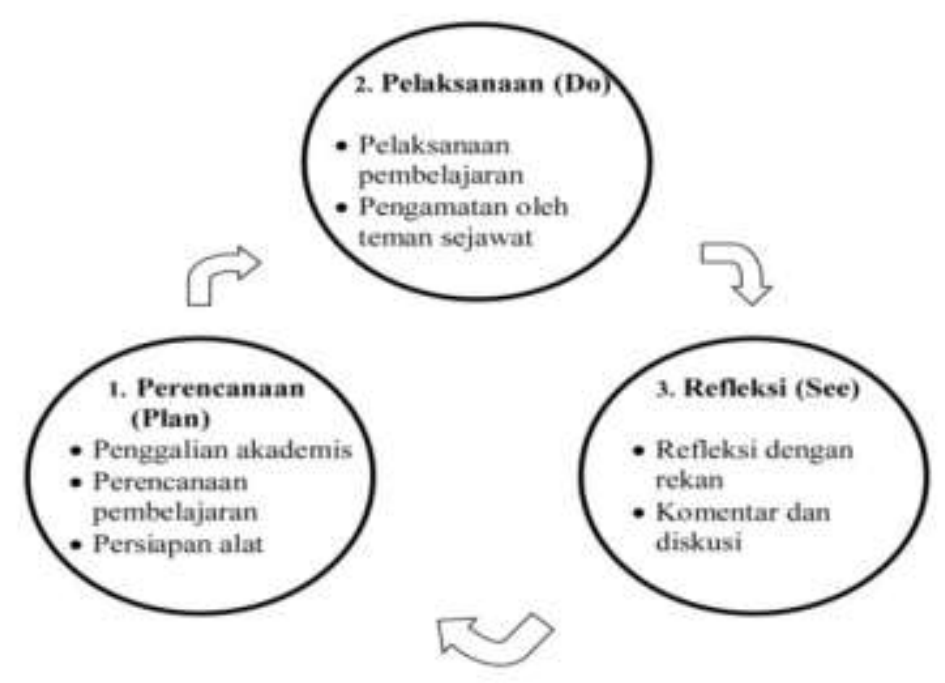

Gambar 1. Daur Kaji Pembelajaran Berorientasi Praktik

Lesson study sebagai kegiatan yang baru diterapkan dalam proses perkuliahan Bimbingan Perawatan Anak (BPA) pada Program Studi Pendidikan Kesejahteraan Keluarga (PKK) FPTK UPI perlu terus digalakan atau dikembangkan untuk peningkatan kualitas mutu pembelajaran. Perkuliahan Bimbingan Perawatan Anak (BPA) pada umumnya cenderung menekankan pada bagaimana dosen mengajar (teacher centered) dan belum menerapkan prinsip student centered learning (pembelajaran yang berpusat pada peserta didik), secara keseluruhan hasilnya dapat di maklumi yang ternyata tidak banyak memberikan kontribusi bagi peningkatan mutu proses dan pembelajaran pada mahasiswa (Ana,2013).

Lesson study dalam perkuliahan Bimbingan Perawatan Anak (BPA) terbatas pada aspek materi pembelajaran baru dapat diimplementasikan pada pokok bahasan Alat Permainan Edukatif (APE) dengan pendekatan Mediated Learning Experience (MLE) untuk peningkatkan kualitas pembelajaran dan aktivitas belajar mahasiswa melalui pengkajian pembelajaran yang telah dirancang secara 
kolaboratif, berkesinambungan dalam merencanakan, melaksanakan, mengobservasi dan melaporkan hasil pembelajaran yaitu mahasiswa termotivasi untuk melakukan proses belajar aktif, adanya interaksi mahasiswa dengan dosen, interaksi antar mahasiswa dan pemahaman materi ajar yang terjadi berawal dari temuan. Pembelajaran yang terjadi adalah mahasiswa mampu menggali materi ajar dan menemukan hubungan antara materi ajar dengan kenyataan dalam kehidupan mahasiswa, sehingga mereka menyadari bahwa dari proses pembelajaran tersebut dapat memposisikan ilmu dan keterampilannya untuk diterapkan dalam kehidupannya. Kegiatan lesson study ini diharapkan bukan hanya bermanfaat bagi dosen pengampu dan para mahasiswa dalam perkuliahan Bimbingan Perawatan Anak (BPA) saja, namun bermanfaat pula bagi dosen lain yang hadir pada saat pembelajaran.

Tujuan umum yang hendak dicapai dalam penelitian ini adalah untuk mengetahui Pelaksanaan Lesson Study dalam Perkuliahan Bimbingan Perawatan Anak pada tahap Plan (Perencanaan), pada tahap Do (Pelaksanaan) dan pada tahap See (Refleksi).

\section{METODE}

Metode yang digunakan pada penelitian ini adalah metode deskriptif analitik dengan pendekatan kualitatif. Subjek penelitian terdiri dari 1 orang Dosen Model, 6 orang Pengamat (Observer), 1 orang fasilitator, dan 26 orang mahasiswa Prodi PKK angkatan 2011 FPTK-UPI yang mengikuti mata kuliah Bimbingan Perawatan Anak, dengan jumlah keseluruhan subjek penelitian adalah 34 orang. Proses analisis data dilakukan dalam tiga tahap yaitu reduksi data, penyajian data (display data), penarikan kesimpulan dan verifikasi.

\section{HASIL DAN PEMBAHASAN}

Tahapan kegiatan yang dilakukan dalam lesson study, seperti perencanaan dan persiapan pembelajaran (plan), implementasi pembelajaran yang dilakukan dalam bentuk open lesson (do), dan refleksi pembelajaran (see) merupakan rangkaian kegiatan pembelajaran yang biasa dilakukan oleh seorang dosen dalam kesehariannya. Pada lesson study yang tidak biasa dilakukan dosen, yaitu bekerja secara kolaboratif untuk melakukan itu semua. Kekuatan dari kegiatan lesson 
study adalah bagaimana kegiatan yang biasa dilakukan dosen itu dikaji, dielaborasi, dan dikembangkan sehingga semua potensi yang dimiliki dapat diberdayakan secara sinergis sehingga menghasilkan suatu kegiatan pembelajaran yang lebih berkualitas dari kegiatan sebelumnya. Suatu kegiatan pembelajaran yang direncanakan dan disiapkan dengan seksama, pelaksanaannya dievaluasi dan direfleksi dengan ketulusan tekad, kejujuran, keterbukaan, dan komitmen yang tinggi untuk melakukan suatu perubahan yang lebih baik.

Pelaksanaan open lesson dari siklus I sampai dengan open lesson siklus III pada pembeajaran BPA, dosen model menggunakan strategi yang sama dan telah melakukan dengan baik sesuai dengan rambu-rabu pembuatan perencanaan.

Pada awal pembelajaran mahasiswa menerima materi (hand out) dari dosen model mengenai konsep dasar Alat Permainan Edukatif (APE) Model RCL melalui pendekatan Mediated Learning Experience (MLE). Proses pembelajaran yang dilakukan dosen yaitu diskusi kelompok. Setelah masing-masing kelompok mahasiswa menerima materi (hand out), mahasiswa membaca dan mempelajari materi tersebut dengan cermat, kemudian mahasiswa melakukan pengkajian materi yang selanjutnya melakukan diskusi serta hasil diskusi kelompok dipresentasikan atau disimulasikan. Berdasarkan data hasil observasi tahapan kegiatan open lesson dari siklus I sampai dengan open lesson siklus III (siklus terakhir) yang dilakukan oleh dosen model bersama dosen PKK sebagai observer pada perkuliahan Bimbingan Perawatan Anak sudah sesuai dengan tahapan kegiatan lesson study yang dipaparkan pedoman lesson study, dimulai dari: perencanaan (Plan), pelaksanaan (Do) dan refleksi (See).

\section{Pelaksanaan Lesson Study dalam Perkuliahan Bimbingan Perawatan Anak pada tahap Perencanaan (Plan)}

Perencanaan merupakan proses yang sangat penting untuk kegiatan pembelajaran. Perencanaan (plan) yang baik tidak dilakukan sendiri tetapi dilakukan bersama beberapa dosen. Dosen sebagai salah satu komponen yang terlibat langsung dalam proses pembelajaran merupakan salah satu faktor penentu dalam keberhasilan mahasiswa dalam memperluas dan mempertajam skill atau kemampuan baik kognitif, afektif maupun psikomotor. 
Dosen model dan dosen PKK FPTK UPI yang tergabung dalam kegiatan Lesson Study telah berkolaborasi dalam merencanakan, melaksanakan, mengobservasi dan melaporkan hasil pembelajaran perkuliahan Bimbingan Perawatan Anak (BPA) agar menjadi lebih baik. Kegiatan yang dilakukan pada tahap perencanaan (plan) pada pelaksanaan lesson study dalam perkuliahan Bimbingan Perawatan Anak berdasarkan pedoman observasi meliputi tiga aspek, sebagai berikut: 1) Mempersiapkan lesson plan; 2) Mempersiapkan format lesson plan; dan 3) Mempersiapkan perangkat pendukung pembelajaran.

Selanjutnya, dosen merancang teaching materials (hands out) berupa LKM (Lembar Kerja Mahasiswa) dan akhirnya dosen berulang-ulang melakukan ini sehingga menyebabkan terbentuknya kolegalitas serta akan terbentuk mutual learning (saling belajar). Selain aspek materi ajar, dosen secara berkelompok perlu mendiskusikan strategi pembelajaran meliputi: pendahuluan, kegiatan inti dan kegiatan akhir. Strategi pembelajaran antara lain meliputi: 1) bagaimana melakukan pendahuluan agar mahasiswa termotivasi untuk melakukan proses belajar aktif sebagaimana yang diharapkan; 2) bagaimana rancangan interaksi mahasiswa dengan materi ajar, 3) bagaimana interaksi antar peserta didik, interaksi mahasiswa dengan dosen; dan 4) bagaimana proses pertukaran hasil belajar (sekarang) antar mahasiswa, serta 5) bagaimana aktivitas mahasiswa pada bagian akhir pembelajaran.

Kegiatan-kegiatan yang dilakukan pada tahap perencanaan pembelajaran (plan) sesuai dengan tahapan lesson study, diuraikan sebagai berikut:

1) Tiap kelompok lesson study menyusun tabel rencana kegiatan lesson study selama satu semester. Tabel rencana tersebut memuat sekurang-kurangnya: siklus ke, hari dan tanggal (sesuai jadwal), materi perkuliahan, kegiatan (pendahuluan, kegiatan inti dan kegiatan akhir), penyusunan perangkat perkuliahan (Satuan Acara Perkuliahan (SAP), media pembelajaran, hand out, dosen yang melakukan perkuliahan, pimpinan diskusi dan keterangan). Satu siklus terdiri dari kegiatan-kegiatan perencanaan, tatap muka perkuliahan dan konservasi, refleksi.

2) Rencana lesson study yang telah disusun lengkap ini digandakan untuk peserta dan diserahkan pada koordinator lesson study fakultas atau jurusan untuk keperluan monitoring dan evaluasi (monev).

3) Dari tabel rencana kegiatan lesson study tersebut tampak adanya pembagian tugas dari setiap anggota kelompok, selanjutnya berdasarkan fokus lesson study yang dipilih, disusun prangkat perkuliahan untuk siklus pertama. 
4) Satuan Acara Perkuliahan (SAP) disusun secara lengkap yang merupakan suatu model perkuliahan sesuai dengan fokus lesson study yang telah ditetapkan. Dengan demikian, seorang pembaca SAP akan memahami dan dapat melaksanakan perkuliahan dikelasnya seperti yang dilakukan oleh penyusun SAP, baik dari segi materi ajarnya dan urutan penyajiannya.

5) Lembar observasi perkuliahan digunakan oleh dosen pengamat untuk melakukan observasi. Pengamatan ditekankan pada kegiatan belajar mahasiswa sebagai akibat dari fokus lesson study yang diberikan. Dengan demikian, lembar observasi berisi hal-hal penting dari fokus lesson study yang harus diamati. Salah satu kegagalan lesson study adalah kurang cermatnya dalam observasi kegiatan belajar mahasiswa.

6) Perangkat perkuliahan yang telah disusun oleh seorang atau beberapa dosen didiskusikan bersama dalam kelompok untuk memperoleh kesepakatan dan kelayakan penerapan pada praktek perkuliahan.

\section{Pelaksanaan Lesson Study dalam Perkuliahan Bimbingan Perawatan} Anak pada tahap Pelaksanaan (Do)

Tahap Pelaksanaan (Do) merupakan tahap yang sangat penting dalam lesson study yaitu mengimplementasikan rencana pembelajaran yang telah disusun secara kolaboratif agar berdampak pada hasil yang diharapkan yaitu pemahaman materi ajar yang terjadi pada mahasiswa berawal dari temuan, pembelajaran yang terjadi adalah bagaimana mahasiswa mampu menggali materi ajar dan menemukan hubungan antar materi ajar dengan kenyataan dalam kehidupan mahasiswa, sehingga mereka menyadari bahwa dari proses pembelajaran tersebut mampu menjadikan dan memposisikan ilmu serta keterampilan untuk diterapkan dalam kehidupan nyata.

Dosen model telah mengimplementasikan rencana pembelajaran yang telah disusun secara berkolaboratif bersama dosen PKK FPTK UPI dengan baik sesuai dengan Satuan Acara Perkuliahan (SAP) yang mencerminkan pembelajaran yang berpusat pada mahasiswa (student centered learning). Pada pelaksanaan open lesson dari siklus I sampai dengan open lesson siklus III dosen model menggunakan strategi pembelajaran yang sama. Proses pembelajaran yang dilakukan dosen yaitu diskusi kelompok dan sebagai bahan referensi atau materi ajar bagi mahasiswa dosen model membuat teaching materials (hands out) berupa LKM (Lembar Kerja Mahasiswa).

Pada saat pelaksanaan (do) dosen PKK FPTK UPI selaku observer, melakukan pengamatan dan mencatat semua yang terjadi selama kegiatan open 
lesson berlangsung. Observasi ini dilakukan sebagai bahan acuan dosen model agar dapat terus meningkatkan kualitas proses pembelajaran dan untuk menemukan hal-hal yang sesungguhnya terjadi selama proses pembelajaran dilakukan. Kegiatan yang dilakukan pada tahap pelaksanaan (do) pada pelaksanaan lesson study dalam perkuliahan Bimbingan Perawatan Anak berdasarkan pedoman observasi meliputi empat aspek, sebagai berikut: 1) Melakukan open lesson; 2) Menggunakan strategi pembelajaran (pendahuluan, inti, dan penutup); 3) Menggunakan perangkat pendukung open lesson; dan 4) Menggunakan setting kelas open lesson.

Selanjutnya, dalam proses pembelajaran dengan menerapkan lesson study bercirikan hadirnya pengamat (observer) dalam ruang pembelajaran atau kelas. Fokus pengamatan ditujukan pada interaksi antar mahasiswa, mahasiswa dengan materi ajar, mahasiswa dengan dosen, dan mahasiswa dengan lingkungan, terkait dengan 4 (empat) kompetensi dosen sesuai dengan UU No.14 tahun 2005 tentang guru dan dosen. Para pengamat, sebelum pembelajaran dimulai diinformasikan aturan selama pembelajaran berlangsung, seperti: tidak boleh berbicara dengan sesama pengamat, pengamat dapat melakukan perekaman video kamera untuk keperluan dokumentasi dan bahan studi lebih lanjut.

Keberadaan pengamat (observer) di dalam ruangan di samping mengumpulkan informasi, dimaksudkan untuk belajar dari pembelajaran yang sedang berlangsung, bukan untuk mengevaluasi dosen model. Pada saat pembelajaran sampai akhir pembelajaran berpatokan pada empat pedoman penelitian (observasi): 1) bagaimana interaksi yang terjadi antar mahasiswa; 2) bagaimana interaksi mahasiswa dengan dosen; 3) bagaimana eksplorasi pemahan materi ajar pada mahasiswa; dan 4) manfaat apa yang didapatkan dari pembelajaran hari ini.

Kegiatan-kegiatan yang dilakukan pada tahap pelaksanaan (do) sesuai dengan tahapan lesson study, adalah sebagai berikut:

1) Dosen yang ditunjuk (sesuai rencana yang telah disusun) melaksanakan perkuliahan dalam kelas sesuai dengan rencana perkuliahan yang telah disepakati bersama, sedangkan dosen lainnya dalam kelompok mengamati jalannya perkuliahan. Jika ada pengamat tambahan dapat berasal dari kelompok mata kuliah lain, atau bahkan dari pimpinan atau masyarakat yang berminat. 
2) Pengamat dengan membawa lembar observasi dan SAP mengambil tempat disisi bagian sisi kiri, kanan, depan atau belakang tempat duduk mahasiswa, yang penting dapat melihat wajah dan gerak-gerik tubuh mahasiswa. Sekali lagi bahwa pengamatan ditekankan pada kegiatan belajar mahasiswa, apakah dengan penerapan SAP yang telah disusun bersama tersebut mahasiswa tampak belajar dengan motivasi dan semangat tinggi, kelas menjadi hidup, atau ada mahasiswa yang memerlukan perhatian khusus, atau hal-hal lainnya yang penting terkait dengan proses pembelajaran.

3) Pada dasarnya pengamat tidak boleh melakukan intervensi selama melakukan pengamatan, baik terhadap dosen maupun mahasiswa. Secara lebih detil rambu-rambu yang harus diperhatikan oleh pengamat akan diuraikan sebagai berikut:

a) Pengamat dan pengamat tambahan lainnya hendaknya datang paling lambat 5 menit sebelum pembelajaran dimulai, dan menyiapkan lembar observasi atau buku catatan dan pena. Jika memungkinkan setiap peserta memperoleh SAP dan LKM atau perangkat pembelajaran lainnya yang telah diperbanyak untuk para pengamat.

b) Semua peserta segera memasuki kelas dengan tertib pada waktu yang ditentukan. Begitu memasuki ruangan semua peserta dan undangan hendaknya tidak lagi berkeinginan keluar masuk kelas, tetaplah berada di dalam kelas dan bersiap mengamati proses pembelajaran.

c) Pengamat segera menempati posisi sedemikian hingga dapat memperhatikan perubahan wajah dan gerak-gerik mahasiswa ketika belajar. Posisi yang ideal adalah dihadapan mahasiswa. Namun, jika mahasiswa berdiskusi berhadapan, posisi yang ideal adalah disamping kelompok.

d) Pada awalnya, setiap pengamat berlatih mengamati satu kelompok. Kelak jika lebih dari 5 kali pengamatan, pengamat dapat mengamati beberapa kelompok lain sehingga dapat mengetahui atmosfer kelas secara keseluruhan.

e) Tidak membantu dosen model dalam proses pembelajaran dalam bentuk apapun. Misalnya ikut dalam pembagian LKM, menenangkan mahasiswa, dan lain-lain. Biarlah dosen model yang melakukan tugasnya secara mandiri dan terbebas dari intervensi siapapun.

f) Tidak membantu mahasiswa dalam proses pembelajaran, misalnya mengarahkan pekerjaan mahasiswa. Jika mahasiswa bertanya kepada anda (sebagai observer), katakan agar mahasiswa bertanya langsung kepada dosen.

g) Tidak mengganggu pandangan dosen atau mahasiswa selama pembelajaran. Jika sedang mendekati kelompok atau berada ditengahtengah kelas, kemudian tiba-tiba dosen ingin memberikan arahan secara klasikal maka segeralah menepi agar tidak mengganggu pandangan mahasiswa.

h) Tidak mengganggu konsentrasi mahasiswa dalam belajar, misalnya berbicara dengan pengamat lain, keluar masuk ruangan.

i) Jika menggunakan kamera untuk mengambil gambar kegiatan belajar (dosen atau mahasiswa) lampu kilat hendaknya dimatikan. Kilatan lampu 
kamera dapat mengganggu atau menghentikan konsentrasi belajar mahasiswa.

j) Observer tidak makan, minum atau merokok didalam ruangan pembelajaran.

k) Observer memfokuskan pada pengamatan pada siswa belajar, bukan hanya pada dosen mengajar. Gunakan lembar pengamatan yang tersedia. Jika fenomena yang diamati tidak tercantum didalam lembar observasi, pengamat dapat menambahkannya.

1) Pengamat melakukan pengamatan secara penuh sejak awal sampai akhir pembelajaran.

m) Selain mengamati mahasiswa belajar, pengamat juga perlu memperhatikan:

(1) Teknik pengelolaan kelas yang dibuat oleh dosen.

(2) Bagaimana dosen mengefektifkan pencapaian tujuan pembelajaran?

(3) Bagaimana dosen memanfaatkan media pembelajaran sederhana dari lingkungan?

(4) Bagaimana upaya dosen membuat mahasiswa kreatif?

\section{Pelaksanaan Lesson Study dalam Perkuliahan Bimbingan Perawatan}

\section{Anak pada tahap Refleksi (See)}

Tahap Refleksi (See) merupakan kegiatan yang penting dan ditunggu para observer serta dosen model, karena pada kegiatan ini akan terjadi interaksi yang sangat membantu dosen model untuk menemukan hal-hal yang sesungguhnya terjadi selama proses pembelajaran dilakukan, serta bagi observer sendiri kegiatan refreksi merupakan bahan evaluasi untuk persiapan dan pelaksanaan pembelajaran yang lebih baik dimasa yang akan datang. Refleksi (see) sebaiknya dilaksanakan segera setelah selesai pembelajaran, hal ini dimaksudkan agar setiap kejadian yang diamati akan dijadikan bukti pada saat mengajukan pendapat dan saran, sehingga tidak banyak terpengaruh oleh temuan dari observer lain karena setiap observer masih banyak menggugat rangkaian aktivitas yang terjadi di dalam kelas. Pada langkah ini observer akan saling berbagi serta berdiskusi atas pengalaman yang telah diamatinya.

Pada saat Refleksi (See) dosen PKK selaku observer memberikan keterangan berkaitan dengan hasil pengamatan pada saat open lesson dilaksanakan, berdasarkan temuan atau kejadian yang sesungguhnya terjadi selama proses pembelajaran berlangsung baik dari kelompok yang diamati maupun secara klasikal. Temuan dan masukan yang disampaikan observer terfokus pada proses belajar mahasiswa, bukan pada aktivitas dosen yang 
mengajar. Refleksi (see) dilakukan setelah selesai pembelajaran, hal ini dimaksudkan agar setiap kejadian yang diamati akan dijadikan bukti pada saat mengajukan pendapat dan saran.

Hasil refleksi yang dilakukan dosen PKK FPTK UPI selaku observer dapat diperoleh sejumlah pengetahuan baru atau keputusan-keputusan penting guna perbaikan dan peningkatan proses pembelajaran serta menjadi modal bagi dosen, baik yang bertindak sebagai pengajar (dosen model) maupun yang bertindak sebagai observer untuk mengembangkan proses pembelajaran ke arah lebih baik.

Kegiatan yang dilakukan pada tahap refleksi (see) pada pelaksanaan lesson study dalam perkuliahan Bimbingan Perawatan Anak berdasarkan pedoman observasi meliputi empat belas aspek, sebagai berikut: 1) Fasilitator mengenalkan observer dengan spesifikasi bidang ilmu; 2) Fasilitator menyampaikan agenda refleksi; 3) Observer berbicara dengan tertib; 4) Observer berbicara sopan tidak untuk mengadili dosen model; 5) Observer diberi kesempatan berbicara; 6) Observer berbicara berdasarkan temuan pengamatan; 7) Masukan observer difokuskan pada "bagaimana mahasiswa belajar?"; 8) Dosen model menyampaikan kejadian yang sesuai dengan harapan; 9) Dosen model menyampaikan kejadian yang tidak sesuai dengan harapan; 10) Dosen model menyampaikan sesuatu yang berubah dari rencana; 11) Team pengembang memberi komentar; 12) Fasilitator memberi kesempatan observer berkomentar; 13) Fasilitator mempersilahkan tenaga ahli merangkum diskusi; dan 14) Fasilitator mengucapkan terima kasih dan mengumumkan kegiatan lesson study selanjutnya.

Dalam hal ini, kegiatan pada tahap refleksi (see) yang telah dilakukan oleh dosen model dan dosen PKK sebagai observer sejalan dengan pendapat Sato (2007:13) menyampaikan prinsip-prinsip dasar diskusi agar dapat membangun kolegalitas, yakni sebagai berikut:

Pertama; objek diskusi harus tidak ditekankan pada cara mengajar yang sebaiknya dilakukan dosen, namun ditekankan pada fakta-fakta mengenai kapan mahasiswa belajar dan kapan mahasiswa tidak dapat belajar. Kedua; dalam diskusi para pengamat sebaiknya tidak memberi saran pada dosen yang diamati, tetapi para pengamat belajar melalui pelajaran yang mereka amati. Pembelajaran timbal balik terwujud ketika pertukaran berbagai pendapat terjadi. Ketiga; dalam diskusi lesson study, setiap peserta setidaknya harus memiliki kesempatan untuk berbicara, sehingga diskusi yang bersifat demokratis akan terwujud. 
Kegiatan-kegiatan yang dilakukan pada tahap refleksi (see) sesuai dengan tahapan lesson study sebagai berikut:

1. Diskusi refleksi dipimpin oleh seorang moderator (fasilitator) dan jika perlu ada notulis.

2. Lebih dulu dosen yang mengimplementasikan rencana perkuliahan (dosen model) oleh moderator (fasilitator) diberikan kesempatan untuk menyampaikan kesan dan hal lain yang dipandang penting dalam mengimplementasikan hasil perkuliahan.

3. Para pengamat menyampaikan tanggapan atau hal-hal penting dalam pelaksanaan perkuliahan yang perlu perbaikan atau perlu dilanjutkan pada siklus berikutnya. Hal yang disampaikan oleh pengamat harus didasarkan pada hasil analisi dari pengamatannya, bukan hanya berdasarkan pada teori atau opini.

4. Agar pelaksanaan refleksi berjalan dengan baik, maka perlu diperhatikan rambu-rambu dalam menyampaikan komentar dalam diskusi refleksi berikut ini:

a) Komentar yang disampaikan sebaiknya terfokus pada masalah proses belajar mahasiswa, bukan pada aktivitas dosen yang mengajar.

b) Apabila terkait dengan kinerja dosen saran disampaikan sebaiknya dengan memperbanyak pujian positif dan sedikit mungkin kritik negatif.

c) Komentar yang disampaikan harus berdasarkan data pengamatan saat observasi, bukan bagaimana seharusnya berdasarkan keinginan pengamat. Artinya jauhkan dari komentar yang menggurui dosen model.

d) Gunakan nada atau suara yang lembut dan pilihan kata yang halus.

e) Komentar yang disampaikan sebaiknya jauh dari sifat menggurui atau menurut pandangannya sendiri.

f) Jika menyampaikan data tentang mahasiswa, kemukakan mengapa hal itu terjadi (ini merupakan interpretasi) dan bagaimana jalan keluarnya (ini merupakan saran untuk perbaikan pembelajaran selanjutnya).

g) Kemukakan juga pelajaran apa yang dapat dipetik dari permasalahan tersebut.

5. Jika ada pakar atau nara sumber yang hadir maka diberi kesempatan untuk menyampaikan komentar akhir, untuk memberi masukan tentang pembelajaran atau proses lesson study.

6. Pada akhir kegiatan refleksi, moderator menyampaikan ringkasan hasil diskusi atau kesimpulan yang dianggap penting. Hasil tersebut berupa hal-hal yang baik untuk dilanjutkan dan saran-saran perbaikan sebagai pertimbangan dalam menyusun perencanaan perkuliahan berikutnya.

Dari hasil refleksi dapat diperoleh sejumlah pengetahuan baru atau keputusan-keputusan penting guna perbaikan dan peningkatan proses pembelajaran. Berbagai temuan dan masukan berharga yang disampaikan pada saat diskusi dalam tahapan refleksi (see) tentunya menjadi modal bagi para dosen, baik yang bertindak sebagai pengajar maupun observer untuk mengembangkan proses pembelajaran ke arah lebih baik. 
Observer melakukan pengamatan dan mencatat semua yang terjadi selama kegiatan open lesson berlangsung. Kegiatan observasi ini dilakukan sebagai bahan acuan dosen agar terus dapat meningkatkan kualitas proses pembelajaran dan bahan refleksi siklus selanjutnya. Observer memberikan keterangan berkaitan dengan hasil pengamatan pada saat open lesson dilaksanakan, berdasarkan temuan atau kejadian yang sesungguhnya terjadi selama proses pembelajaran, baik dari kelompok yang diamati maupun secara klasikal. Temuan dan masukan yang disampaikan terfokus pada masalah proses belajar mahasiswa, bukan pada aktivitas dosen yang mengajar.

Kegiatan lesson study yang dilaksanakan pada perkuliahan Bimbingan Perawatan Anak sudah menunjukkan bahwa kemampuan dosen dalam merencanakan, melaksanakan dan merefleksikan pembelajaran berproses menjadi lebih baik sesuai dengan tuntutan Mata Kuliah. Walaupun keberhasilan dari kegiatan ini belum diukur berdasarkan tes hasil belajar mahasiswa. Dengan demikian, asumsi yang bisa dirumuskan adalah bahwa hasil pembelajaran yang lebih baik akan diperoleh dari proses pembelajaran yang lebih baik.

Keberhasilan dari lesson study bukanlah prestasi seseorang dalam waktu sesaat, namun merupakan pencapaian hasil dari suatu proses kolaborasi banyak pihak terutama antar sesama dosen, fasilitator, dan pihak lain yang memiliki kepentingan sama dalam meningkatkan kualitas pendidikan, yang dilakukan secara berkesinambungan. Kesungguhan tekad, keterbukaan, dan kebersamaan semua pihak yang berkolaborasi inilah yang akan menentukan kegiatan lesson study. Dengan demikian pihak yang bekerjasama dengan sungguh-sungguh yang dapat menentukan keberhasilan lesson study diantaranya adalah dosen model, fasilitator, dan observer.

Selain itu, kegiatan lesson study yang diimplementasikan pada mata kuliah Bimbingan Perawatan Anak (BPA) efektif untuk menanamkan: (1) mahasiswa lebih bersemangat dan lebih aktif menyimak materi pembelajaran yang disampaikan dosen model, (2) tidak ada mahasiswa yang terlambat masuk kelas, (3) program lesson study dapat melatih kemandirian dan cara berpikir aktif mahasiswa dalam belajar, (4) dosen model dalam menyusun materi (hand out) 
lebih rinci. Dengan kata lain, dapat disimpulkan bahwa tujuan penelitian ini dapat tercapai dengan baik.

\section{KESIMPULAN}

Tahapan plan pada kegiatan lesson study telah dilaksanakan dengan baik sesuai dengan pedoman lesson study. Dosen Prodi PKK FPTK UPI yang tergabung dalam kegiatan lesson study telah berkolaborasi dalam merencanakan pembelajaran Bimbingan Perawatan Anak (BPA) dari open lesson siklus 1 sampai open lesson siklus III, meliputi tiga aspek, yaitu 1) Mempersiapkan lesson plan; 2) Mempersiapkan format lesson plan; dan 3) Mempersiapkan perangkat pendukung pembelajaran dengan membuat teaching materials (hands out) berupa LKM (Lembar Kerja Mahasiswa).

Dosen model telah melaksanakan rencana pembelajaran yang telah disusun secara berkolaboratif bersama dosen PKK FPTK UPI dengan baik sesuai dengan Satuan Acara Perkuliahan (SAP) berdasarkan pembelajaran yang berpusat pada mahasiswa (student centered learning). Pada pelaksanaan open lesson siklus I sampai open lesson siklus III dosen model menggunakan strategi pembelajaran yang sama. Proses pembelajaran yang dilakukan dosen yaitu diskusi kelompok, simulasi dan penugasan. Kegiatan yang dilakukan pada tahap pelaksanaan (do) pada pelaksanaan lesson study dalam perkuliahan Bimbingan Perawatan Anak, dosen model sudah melaksanakan dengan baik sesuai dengan pedoman lesson study, meliputi empat aspek, sebagai berikut: 1) Melakukan open lesson; 2) Menggunakan strategi pembelajaran (pendahuluan, inti, dan penutup); 3) Menggunakan perangkat pendukung open lesson; dan 4) Menggunakan setting kelas open lesson.

Kegiatan yang dilakukan pada tahap Refleksi (see) pada pelaksanaan lesson study dalam perkuliahan Bimbingan Perawatan Anak, dosen model, fasilitator dan dosen PKK FPTK UPI selaku observer sudah melaksanakan dengan baik sesuai dengan pedoman lesson study, meliputi empat belas aspek, sebagai berikut: 1) Fasilitator mengenalkan observer dengan spesifikasi bidang ilmu; 2) Fasilitator menyampaikan agenda refleksi; 3) Observer berbicara dengan tertib; 4) Observer berbicara sopan tidak untuk mengadili dosen model; 5) Observer diberi 
kesempatan berbicara; 6) Observer berbicara berdasarkan temuan pengamatan; 7) Masukan observer difokuskan pada "bagaimana mahasiswa belajar?"; 8) Dosen model menyampaikan kejadian yang sesuai dengan harapan; 9) Dosen model menyampaikan kejadian yang tidak sesuai dengan harapan; 10) Dosen model menyampaikan sesuatu yang berubah dari rencana; 11) Team pengembang memberi komentar; 12) Fasilitator memberi kesempatan observer berkomentar; 13) Fasilitator mempersilahkan tenaga ahli merangkum diskusi; dan 14) Fasilitator mengucapkan terima kasih dan mengumumkan kegiatan lesson study selanjutnya.

\section{DAFTAR PUSTAKA}

Ana. (2013). Pengembangan Model Reflective and Collaborative Learning (RCL) Untuk Meningkatkan Kualitas Pembelajaran Melalui Kegiatan Lesson Study (Proposal). Bandung: Tidak Diterbitkan

Ibrohim. (2011). Pengaruh Lesson Study Terhadap Peningkatan Kompetensi Guru Dan Perkembangannya Di Indonesia (ToT Program InduksiGuru Pemula, Hotel Grand Jaya Raya, Puncak - Cipayung Bogor, 16-20Mei 2011). FMIPA-Universitas Negeri Malang.

.(2011). Konsep dan Prinsip Lesson Study Untuk Meningkatkan Kompetensi dan Profesionalitas Pendidik (Dosen dan Guru). (Workshop Lesson Study dalam implementasi Program LEDIPSTI di Jurusan MIPA, FKIP UMM Malang, 17 Februari 2011).Universitas Negeri Malang.

Sato, Manabu (2007). Tantangan yang Harus Dihadapi Sekolah, makalah dalam Bacaan Rujukan untuk Lesson Study - Berdasarkan Pengalaman Jepang dan IMSTEP. Jakarta: Sisttems.

Undang, Gunawan. (2009). Lesson Study (Model Pengkajian Pembelajaran Kolaboratif). Bandung: Sayagatama Press.

Universitas Pendidikan Indonesia. (2012). Pedoman Penulisan Karya Ilmiah. Bandung.

Peraturan Pemerintah No.19 Tahun 2005 tentang Standar Nasional Pendidikan, Bab IV pasal 19 ayat 1.

Undang-Undang Republik Indonesia Nomor 14 Tahun 2005 Tentang Guru dan Dosen. 